\title{
24. ALKALI AND Sr ISOTOPE GEOCHEMISTRY OF WATERS COLLECTED FROM BASALTIC BASEMENT, DEEP SEA DRILLING PROJECT HOLE 504B, COSTA RICA RIFT ${ }^{1}$
}

\author{
S. R. Hart, Department of Earth and Planetary Sciences, Massachusetts Institute of Technology, \\ Cambridge, Massachusetts \\ and \\ M. J. Mottl, Department of Chemistry, Woods Hole Oceanographic Institution, Woods Hole, Massachusetts
}

\begin{abstract}
Basalt formation waters collected from Hole 504B at sub-basement depths of 194, 201, 365, and 440 meters show inverse linear relationships between ${ }^{87} \mathrm{Sr} /{ }^{86} \mathrm{Sr}$ and $\mathrm{Ca},{ }^{87} \mathrm{Sr} /{ }^{86} \mathrm{Sr}$ and $\mathrm{Sr}$, and $\mathrm{K}$ and $\mathrm{Ca}$. If the $\mathrm{Ca}$ content of a fully reacted formation water end-member is assumed to be $1340 \mathrm{ppm}$, the $\mathrm{K}, \mathrm{Sr}$, and ${ }^{87} \mathrm{Sr} /{ }^{86} \mathrm{Sr}$ values for the end-member are 334 ppm, $7.67 \mathrm{ppm}$, and 0.70836 , respectively. With respect to contemporary seawater at Hole 504B, K is depleted by $13 \%$, $\mathrm{Sr}$ is enriched by $2.7 \%$, and ${ }^{87} \mathrm{Sr} /{ }^{86} \mathrm{Sr}$ is depleted by $0.8 \%$. The $\mathrm{Sr} / \mathrm{Ca}$ ratio of the formation water $(0.0057)$ is much lower than that of seawater $(0.018)$ but is similar to the submarine hot spring waters from the Galapagos Rift and East Pacific Rise and to geothermal brines from Iceland. At the intermediate temperatures represented by the Hole 504B formation waters $\left(70^{\circ}-105^{\circ} \mathrm{C}\right)$, the interaction between seawater and the ocean crust produces large solution enrichments in $\mathrm{Ca}$, the addition of a significant basalt $\mathrm{Sr}$ isotope component accompanied by only a minor elemental $\mathrm{Sr}$ component, and the removal from solution of seawater $\mathrm{K}$. The $\mathrm{Rb}, \mathrm{Cs}$, and $\mathrm{Ba}$ contents of the formation waters appear to be affected by contamination, possibly from drilling muds.
\end{abstract}

\section{INTRODUCTION}

The thermally driven convection of seawater through newly formed ocean crust is now a well-recognized phenomenon (Elder, 1965; Anderson et al., 1977; Wolery and Sleep, 1976). This convection process has significant potential for influencing the chemistry of seawater through the interaction of the heated seawater with the basalt of the ocean crust. A complete understanding of the chemical fluxes involved in this process depends on knowing the duration of convection and the chemistry of the fluids and solid alteration phases that result from the seawater/basalt interaction. The chemistry of solid alteration phases has received considerable attention recently (e.g., Andrews, 1977; Böhlke et al., 1980; Honnorez et al., 1979; Humphris and Thompson, 1978a, b; Staudigel, Hart, et al., 1981; Staudigel, Muehlenbachs, et al., 1981; Mevel, 1980; Pritchard, 1980; Robinson et al., 1977). The chemistry of the circulating fluids has been studied only in two areas of the ridge system where hot springs of fluids exit the crust (Edmond, Measures, Mangum, et al., 1979; Edmond, Measures, McDuff, et al., 1979; Edmond, 1981); the fluids were sampled directly during both studies. In situ sampling of crustal formation waters during the drilling at Hole 504B, which is in 5.9 m.y. old ocean crust on the Costa Rica Rift, provided another opportunity to study the chemistry of crustal fluids directly. We report here the $\mathrm{K}, \mathrm{Rb}, \mathrm{Cs}$, $\mathrm{Ba}, \mathrm{Sr}$, and $\mathrm{Sr}$ isotope chemistry of the Hole 504B formation waters and compare the chemistry of these moderate temperature fluids (less than $\sim 120^{\circ} \mathrm{C}$ ) with the

\footnotetext{
${ }^{1}$ Cann, J, R., Langseth, M. G., Honnorez, J., Von Herzen, R. P., White, S. M., et al., Init. Repts. DSDP, 69: Washington (U.S. Govt. Printing Office).
}

chemistry of the high temperature hot spring fluids $\left(\sim 350^{\circ} \mathrm{C}\right)$ reported by Edmond et al.

\section{SAMPLING AND ANALYTICAL TECHNIQUES}

A detailed description of the in situ sampling at Hole 504B is given by Mottl et al. (this volume). At first the in situ water samples were believed to represent mixtures of formation waters resident in the basaltic crust and the seawater used for drilling. However, the results of tritium analyses of a number of the samples demonstrated that no true formation water had been retrieved (Mottl et al., this volume). Apparently all the samples were in fact surface seawater that had been pumped into the hole some 5 days before the in situ sampling. This water, which had reacted with the basalt at temperatures of $\sim 70^{\circ} \mathrm{C}$, had a chemical signature that was markedly different from that of surface seawater. The chemistry of the reacted water may also differ from that of true formation water, depending on the extent to which the various elements have approached the true formation water's quasi equilibrium. As discussed by Mottl, Anderson, et al. (this volume), a comparison of $\mathrm{Ca}$ and $\mathrm{Mg}$ in the calculated end-member for this reacted seawater with the $\mathrm{Ca}$ and $\mathrm{Mg}$ in pore waters from the sediments immediately overlying the basalt in Hole 504B suggests that at least the concentration of these two elements may closely approximate that expected for a fully reacted true formation water. Additional support for this idea comes from the chemistry of the in situ waters collected during the deepening of Hole 504B on Leg 70; the $\mathrm{Ca}$ and $\mathrm{Mg}$ contents of these waters (M. J. Mottl, Leg 83 shipboard report) lie along the same mixing curve as the shallower samples, despite the fact that they were collected within 24 hours after drilling was stopped at each depth. These deeper waters were also at a higher temper- 
ature when retrieved $\left(\sim 110^{\circ} \mathrm{C}\right)$, which would presumably lead to more rapid interaction rates than those of the shallower samples. In the following material we will discuss the chemistry of these collected waters as if they in fact have a true formation water component, though the above considerations should be kept firmly in mind throughout.

The samples designated PS-A to PS-5 (Table 1) were collected with the Lynes packer and represent a single collection depth (201 m sub-basement). At this depth the water samples contain variable admixtures of the fresh surface seawater used in drilling. (Because of the nature of the collection device, Sample PS-A contains the least, and Sample PS-5 the greatest, component of fresh seawater.) The PS series of samples thus lie on mixing lines between the surface seawater and the reacted formation water. Samples IW 175 and IW 194, which were acquired with the Barnes in situ sampler and also represent mixtures of surface seawater and reacted formation water, were acquired at depths of 365 and 440 meters sub-basement. Aliquots of these samples were obtained through the courtesy of Dr. Michael Bender. Sample GO-2, which was collected with the Gearhart-Owen wireline sampler and is also a mixture of surface seawater and formation water, was acquired at a depth of 194 meters sub-basement. During the process of aliquoting, storing, and spiking these water samples, some evaporation took place; the corrections for evaporation are discussed in the following material.

The aliquots $(\sim 1 \mathrm{ml})$ received for analysis were spiked with a mixed spike containing isotopically enriched ${ }^{40} \mathrm{~K}$, ${ }^{87} \mathrm{Rb},{ }^{135} \mathrm{Cs},{ }^{136} \mathrm{Ba}$, and ${ }^{84} \mathrm{Sr}$. Conventional cation resin exchange techniques (Aldrich et al., 1953) were used to perform chemical separations; mass spectrometry of the isotope dilution mixtures was performed on the 9-in. fully automated instrument at M.I.T. Blanks for the total analytical procedure were $5 \mathrm{ng} \mathrm{K}, 0.02 \mathrm{ng} \mathrm{Rb}, 0.5$ pg Cs, $2 \mathrm{ng} \mathrm{Ba}$, and $0.1 \mathrm{ng} \mathrm{Sr}$; except for $\mathrm{Ba}$, these blanks were negligible, ranging from $2 \times 10^{-3}$ to $1 \times$ $10^{-5}$ of the sample element carried in the procedure. The Ba blank was $20 \%$ of the surface seawater analysis and $\leq 2 \%$ of the others; all values were corrected for this blank. Spikes were calibrated against gravimetric solutions of high-purity salts, which had accuracies of $\leq 0.3 \%$ for $\mathrm{K}, \mathrm{Ba}$, and $\mathrm{Sr}$ (elements for which fractiona- tion corrections were possible), $\leq 0.6 \%$ for $\mathrm{Rb}$ (for which fractionation was limited), and $\leq 3 \%$ for Cs (for which gravimetry was limited). Exclusive of the effects of evaporation (a problem discussed in the material following), the accuracy of the reported values is $\leq 0.5 \%$ for $\mathrm{K}$ and $\mathrm{Sr}, \leq 1 \%$ for $\mathrm{Rb}$, and $\pm 3 \%$ for $\mathrm{Cs}$ and $\mathrm{Ba}$ (except for $\mathrm{Ba}$ in the surface seawater, which is no better than $\pm 25 \%$ ). Because of the use of a mixed element spike, the precision of the concentrations relative to each other is considerably better than the accuracy of the individual elements. Details of the chemical and mass spectrometric procedures are given in Hart and Brooks (1977).

$\mathrm{Sr}$ isotope analyses were performed on NIMA-B, the 9-in. mass spectrometer at M.I.T. Two-hour runs were sufficient to produce precisions of $\leq 0.01 \%$; standardization was achieved by using the Eimer and Amend (E \& A) Sr standard, which had a mean value, based on multiple runs, of $0.70783 \pm 2$. The values reported here have been normalized to an E \& A value of 0.70800 . The surface seawater sample analyzed has a normalized value of 0.70912 , which compares well with the similarly E \& A adjusted composite seawater value of 0.70907 reported by Hildreth and Henderson (1971). High precision analyses of seawater reported by Papanastassiou and Wasserburg (1978) resulted in a value of 0.70909 ; unfortunately, no E \& A value is available with these data for normalization.

There remains the question of whether the water retrieved from the sampling devices has been contaminated during the sampling process in any way. The uniformity of the values of $\mathrm{K}, \mathrm{Sr}$, and ${ }^{87} \mathrm{Sr} /{ }^{86} \mathrm{Sr}$ from different samples suggests that insofar as these elements are concerned the water is not significantly contaminated. The values of $\mathrm{Rb}, \mathrm{Cs}$, and $\mathrm{Ba}$ are more problematic, inasmuch as they vary from sample to sample; the potential for the contamination of the measurement of these elements is obviously considerable, because bentonitebarite muds were used during various stages of the drilling operation. See also the discussion by Mottl, Anderson, et al. (this volume).

\section{RESULTS}

The concentrations of $\mathrm{K}, \mathrm{Rb}, \mathrm{Cs}, \mathrm{Ba}, \mathrm{Sr}$, and the ${ }^{87} \mathrm{Sr} /{ }^{86} \mathrm{Sr}$ isotope ratios for the various water samples

Table 1. K, Rb, Cs, Ba, and $\mathrm{Sr}$ concentrations and ${ }^{87} \mathrm{Sr} /{ }^{86} \mathrm{Sr}$ ratios of Hole 504B formation water.

\begin{tabular}{|c|c|c|c|c|c|c|c|c|c|c|c|c|}
\hline Sample & $\begin{array}{l}\text { Sub- } \\
\text { basement } \\
\text { Depth } \\
\text { (m) }\end{array}$ & K & $\mathbf{R b}$ & Cs & $\mathrm{Ba}$ & $\mathrm{Sr}$ & ${ }^{87} \mathrm{Sr} /{ }^{86} \mathrm{Sr}$ & $\mathrm{Ca}^{\mathrm{a}}$ & $\mathrm{K} / \mathbf{R b}$ & $\mathrm{K} / \mathrm{Cs}\left(\times 10^{6}\right)$ & $\mathrm{K} / \mathrm{Sr}$ & $\mathrm{K} / \mathrm{Ba}\left(\times 10^{3}\right)$ \\
\hline Surface water & & 376.9 & 0.1048 & 0.301 & 0.009 & 7.47 & $0.70912 \pm 7$ & 409 & 3597 & 1.25 & 50.5 & 41.3 \\
\hline PS-A & 201 & 363.2 & 0.1122 & 0.485 & 0.143 & 7.52 & $0.70889 \pm 6$ & 738 & 3238 & 0.75 & 48.3 & 2.54 \\
\hline PS-1 & 201 & 360.1 & 0.1123 & 0.411 & 0.106 & 7.52 & $0.70883 \pm 7$ & 702 & 3207 & 0.88 & 47.9 & 3.38 \\
\hline PS-2 & 201 & 376.2 & 0.1099 & 0.329 & - & 7.54 & $0.70909 \pm 8$ & 517 & 3424 & 1.14 & 49.9 & - \\
\hline PS-4 & 201 & - & - & - & - & 7.46 & $0.70909 \pm 3$ & 461 & - & - & - & - \\
\hline PS-5 & 201 & 372.6 & 0.1068 & 0.335 & 0.095 & 7.45 & $0.70906 \pm 7$ & 449 & 3489 & 1.11 & 50.0 & 3.91 \\
\hline GO-2 & 194 & 384.7 & 0.1206 & 0.843 & 0.323 & 7.70 & $0.70898 \pm 6$ & 585 & 3190 & 0.46 & 49.9 & 1.19 \\
\hline IW 175 & 365 & 390.1 & 0.1092 & 0.553 & - & 7.66 & $0.70904 \pm 5$ & 462 & 3570 & 0.705 & 50.9 & - \\
\hline IW 194 & 440 & 460.4 & 0.1549 & 1.402 & 0.354 & 9.33 & $0.70898 \pm 5$ & 535 & 2971 & 0.33 & 49.3 & 1.30 \\
\hline
\end{tabular}


are given in Table 1. Also listed are $\mathrm{Ca}$ concentrations, which can be used to determine the relative proportions of surface seawater and reacted formation water in the samples. The best estimate of the $\mathrm{Ca}$ content of the reacted formation water is $\sim 1340 \mathrm{ppm}$ (Mottl et al., this volume), as opposed to $409 \mathrm{ppm}$ in the surface seawater. The proportion of formation water in the samples in Table 1 thus ranges from 4\% (in Sample PS-5) to $35 \%$ (in Sample PS-A). The $\mathrm{Sr}$ isotope ratios and the ratios $\mathrm{K} / \mathrm{Rb}, \mathrm{K} / \mathrm{Cs}, \mathrm{K} / \mathrm{Sr}$, and $\mathrm{K} / \mathrm{Ba}$ are plotted versus $\mathrm{Ca}$ content in Figures 1 to 3 . With the exception discussed hereafter, the PS series samples all fall along a single curve (or mixing line), as they should, since they are points along a curve with the same end-members (mixtures of the same two substances)-formation water and surface seawater. The samples from other sub-basement depths (GO-2, IW 175, and IW 194) fall on the same mixing line as the PS series samples in the $\mathrm{K} / \mathrm{Sr}$ and ${ }^{87} \mathrm{Sr} /{ }^{86} \mathrm{Sr}$ plots but fall significantly below the mixing lines in the $\mathrm{K} / \mathrm{Rb}, \mathrm{K} / \mathrm{Cs}$, and $\mathrm{K} / \mathrm{Ba}$ plots. Taken at face value, this means that the end-member formation waters at all four depths are probably similar in $\mathrm{K}, \mathrm{Sr},{ }^{87} \mathrm{Sr} /$ ${ }^{86} \mathrm{Sr}$, and $\mathrm{Ca}$ content but different in $\mathrm{Rb}, \mathrm{Cs}$, and $\mathrm{Ba}$. This interpretation seems unlikely, however, since Sample GO-2 is from nearly the same depth as the samples in the PS series. In view of the drilling procedures mentioned previously, it seems more likely that the different levels of $\mathrm{Rb}, \mathrm{Cs}$, and $\mathrm{Ba}$ at the different sampling depths simply reflect contamination.

In the PS series samples, the contamination of the water with excess amounts of $\mathrm{Ba}$ is indisputable, since Sample PS- 5 does not lie on the mixing line between seawater and sample PS-A (Fig. 3), as it would if one endmember were uncontaminated seawater. The mixing line actually defined by Samples PS-A, PS-1, and PS- 5 suggests a $\mathrm{Ba}$ content of $\sim 0.08 \mathrm{ppm}$ for the seawater endmember; this is higher than the $\mathrm{Ba}$ content measured in the surface seawater $(0.009 \mathrm{ppm})$, and in fact is higher than the $\mathrm{Ba}$ content in any other seawater by a factor of 4 to 16 (Bernat et al., 1972).

The content of $\mathrm{Rb}$ and $\mathrm{Cs}$ in the PS series does fall on a mixing line through surface seawater and is thus consistent with the assumption of uncontaminated seawater as one end-member. This is to be expected, inasmuch as surface seawater was pumped through the drill hole for 1 hour shortly before the packer sample was taken. It is difficult to prove, however, that the other end-member (formation water) was not mixed with contaminated seawater at some stage prior to sampling, this contaminated end-member then being mixed with pure seawater during the sampling. Samples GO-2 and IW 194 define a negative trend in $\mathrm{Rb}-\mathrm{Ca}$ and $\mathrm{Cs}-\mathrm{Ca}$ plots (not shown), suggesting a mixture between a formation water endmember and a seawater end-member contaminated by $\mathrm{Rb}$ and Cs. This is consistent with the fact that the pumping of surface seawater through the hole was stopped for 3 days before taking Sample GO-2 and 1 day before taking Samples IW 175 and IW 194. Finally, although the $\mathrm{K} / \mathrm{Rb}$ trends in Figure 2 would extrapolate to a reasonable end-member (relative to the hot spring data of Edmond, Measures, McDuff, et al., 1979), it is noteworthy that $\mathrm{K}$ decreases with $\mathrm{Ca}$, whereas $\mathrm{Rb}$ and $\mathrm{Cs}$ increase with $\mathrm{Ca}$. Although it is not impossible that the three alkalies would behave in opposite directions like this, it is more likely that the increased $\mathrm{Rb}$ and Cs contents reflect contamination.

If we assume that the Cs contents are a result of contamination and that the contaminant is derived from

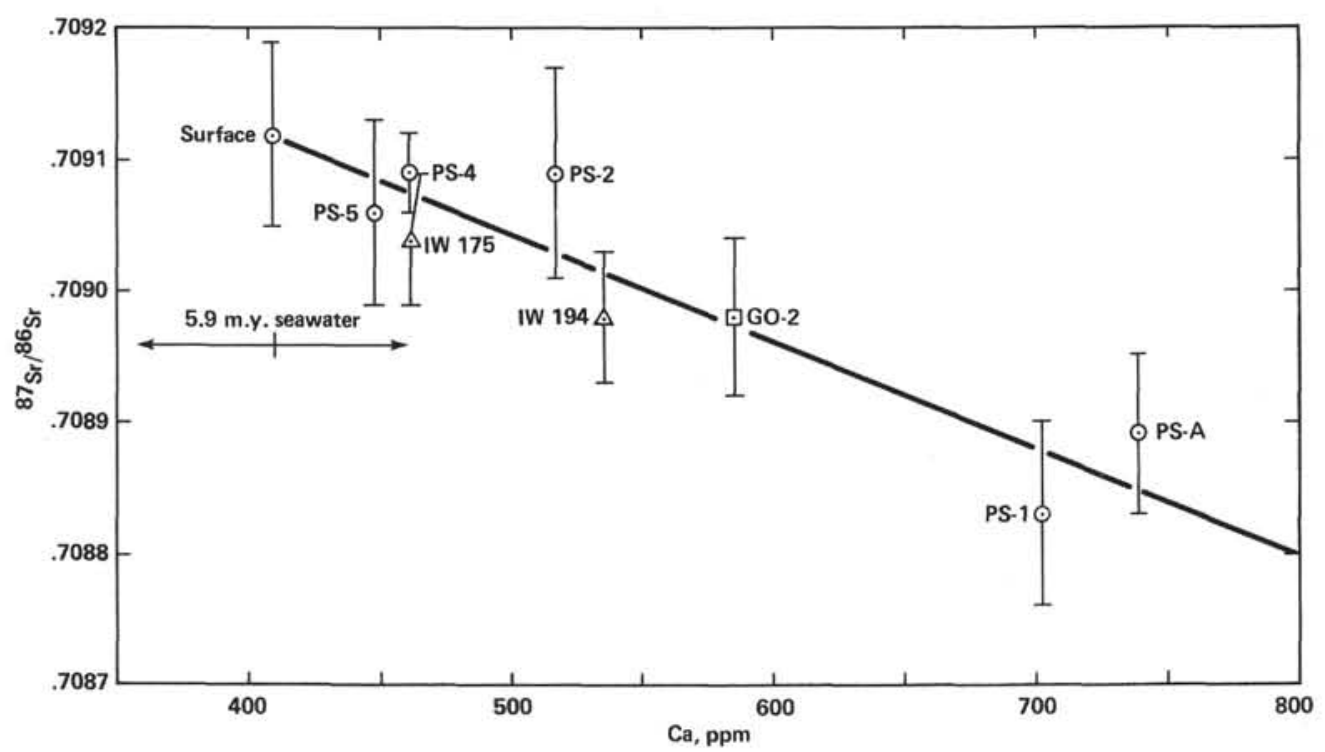

Figure $1 .{ }^{87} \mathrm{Sr} /{ }^{86} \mathrm{Sr}$ ratios of formation water mixtures versus $\mathrm{Ca}$ content. Formation waters sampled at four depths in basement all fall on a single mixing line between modern seawater and a hypothetical fully reacted formation water end-member (at $\mathrm{Ca} \approx 1340 \mathrm{ppm}$ ). Open circles, 201-meter depth; open square, 194-meter depth; open triangles, 365- and 440-meter depth. The $\mathrm{Sr}$ isotope composition of 5.9 m.y. old seawater is shown for comparison. The equation of the mixing line is ${ }^{87} \mathrm{Sr} /{ }^{86} \mathrm{Sr}=0.70945-8.125 \times 10^{-7} \mathrm{Ca}^{\text {pfw }}$ where $\mathrm{pfw}$ is pure formation water. 

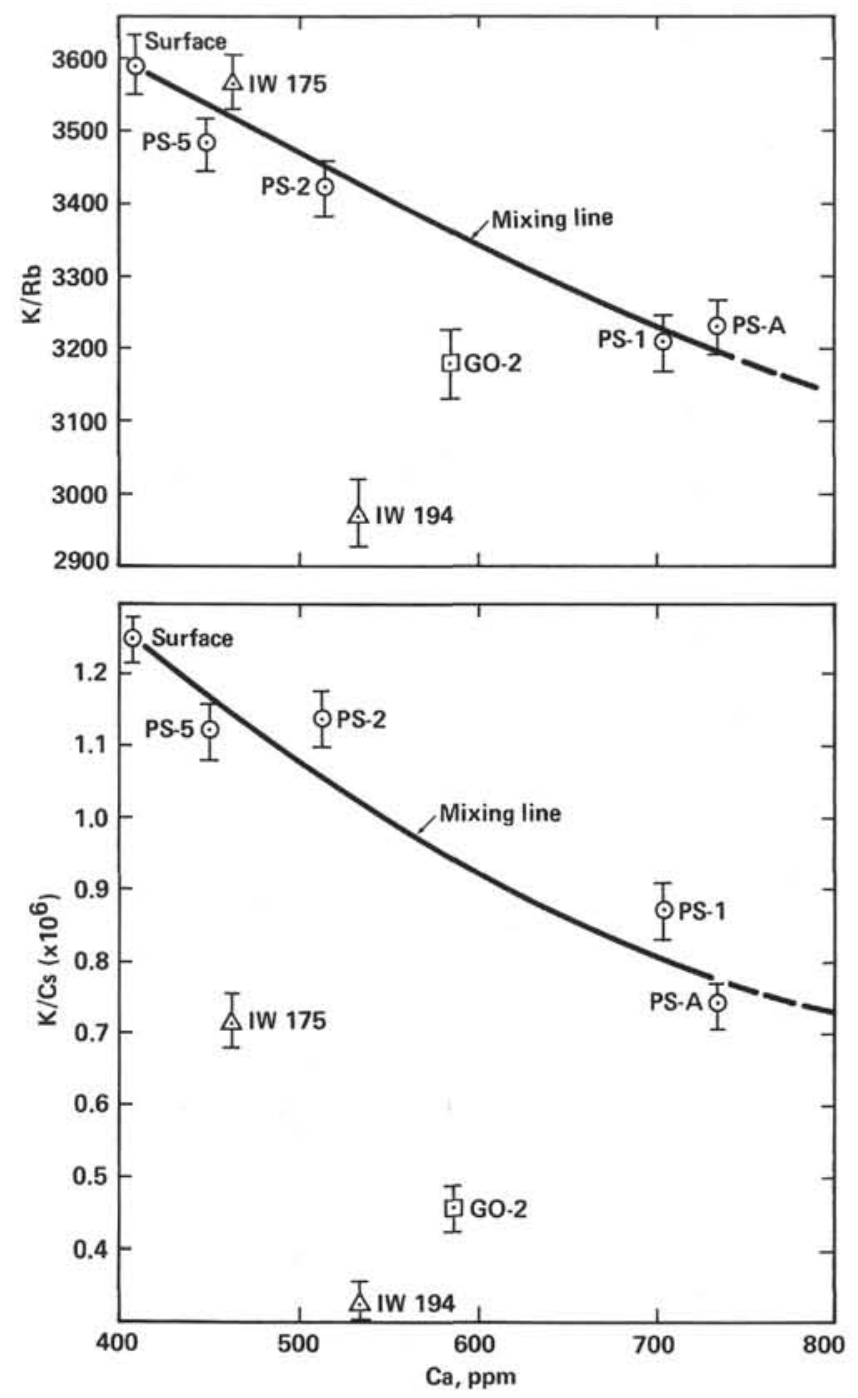

Figure 2. $\mathrm{K} / \mathrm{Rb}$ and $\mathrm{K} / \mathrm{Cs}$ ratios of formation water mixtures versus $\mathrm{Ca}$ content. Errors in $\mathrm{K} / \mathrm{Rb}$ and $\mathrm{K} / \mathrm{Cs}$ are taken to be $\pm 1 \%$ and $\pm 3 \%$, respectively. The error in Ca is negligible on the scale of this diagram. The curve is a best-fit mixing line to the PS series samples (open circles). Note that the samples from other depths do not fit the PS series mixing line, showing that the end-member alkali ratios for these samples must be different from those for the PS series samples.

clays with typical $\mathrm{K} / \mathrm{Rb}$ and $\mathrm{K} / \mathrm{Cs}$ ratios of 250 and 4000 respectively, we can use the Cs contents to estimate the extent to which $\mathrm{Rb}$ and $\mathrm{K}$ are contaminated. This calculation suggests that $\mathrm{K}$ is affected by less than $\sim 0.7 \%$ and $\mathrm{Rb}$ by less than $10 \%$; thus, the $\mathrm{K}$ data are relatively insensitive to possible contamination relative to the range observed $(5 \%)$, whereas the $R b$ effect could be a large part of the range observed $(\sim 20 \%)$. We conclude that the $\mathrm{Rb}, \mathrm{Cs}$, and $\mathrm{Ba}$ data must be treated as suspect. The $\mathrm{K}$ and $\mathrm{Sr}$ data, on the other hand, are unlikely to be seriously affected by contamination, principally because of their high concentrations relative to $\mathrm{Cs}$ and $\mathrm{Ba}$. (The $\mathrm{K} / \mathrm{Cs}$ and $\mathrm{Sr} / \mathrm{Ba}$ ratios of the waters are several orders of magnitude larger than these ratios in clays, sediments, basalts, and so forth.)
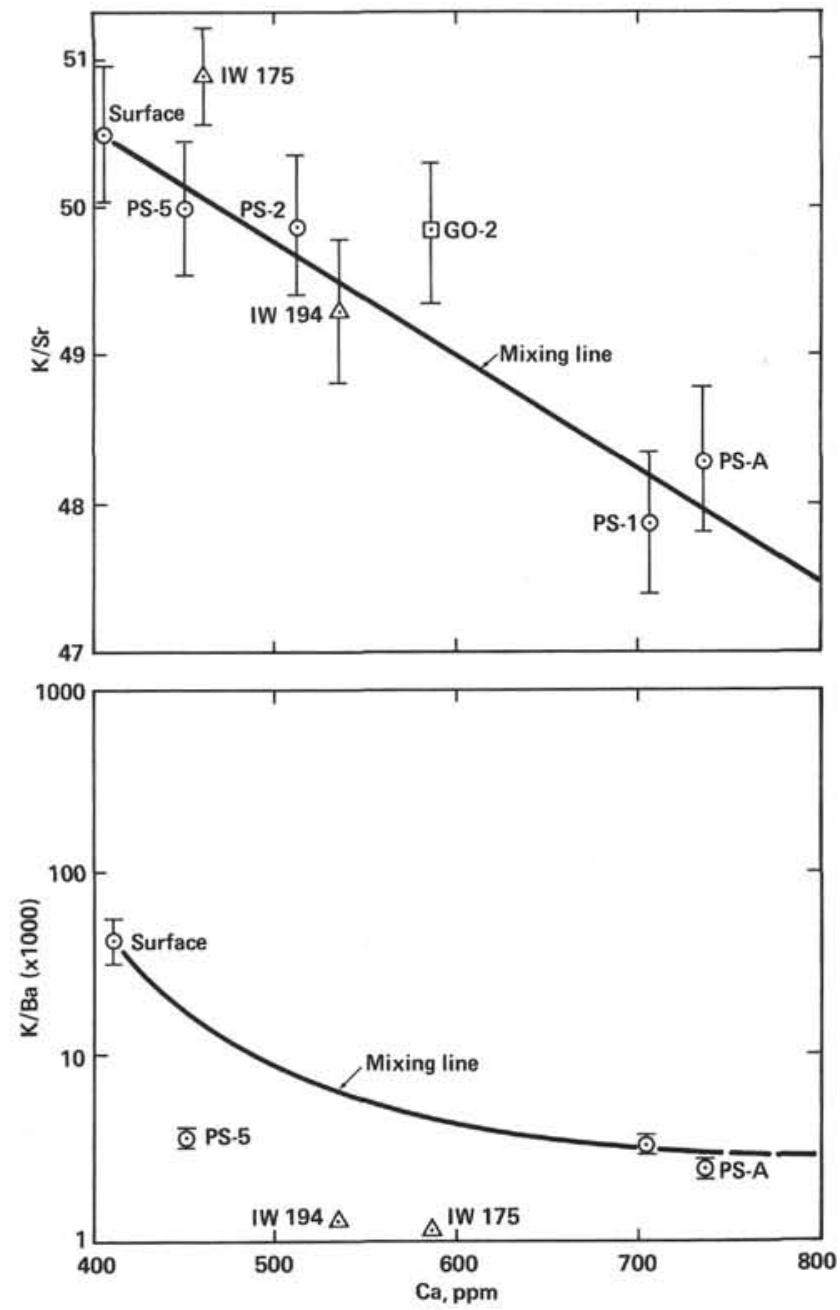

Figure 3. $\mathrm{K} / \mathrm{Sr}$ and $\mathrm{K} / \mathrm{Ba}$ ratios of formation water mixture versus $\mathrm{Ca}$ content. Errors in $\mathrm{K} / \mathrm{Sr}$ and $\mathrm{K} / \mathrm{Ba}$ are taken to be $\pm 1 \%$ and $\pm 3 \%$, respectively (except for $\mathrm{K} / \mathrm{Ba}$ for surface water, which is $\pm 25 \%$ ). The various samples approximate a single mixing line for $\mathrm{K} / \mathrm{Sr}$ versus $\mathrm{Ca}$ but not for $\mathrm{K} / \mathrm{Ba}$.

Thus far, we have considered the data principally in the form of element ratios to avoid the analytical complications necessary to account for the evaporation that occurred during the handling of the samples. Samples IW 175 and IW 194, which were stored in screw cap vials before being spiked, are known to have undergone evaporation (note the high Sr concentration of IW 194 relative to the other waters). We made a first-order correction for the effects of evaporation by noting that the $\mathrm{K} / \mathrm{Sr}$ and ${ }^{87} \mathrm{Sr} /{ }^{86} \mathrm{Sr}$ versus $\mathrm{Ca}$ plots suggest a similar formation water end-member for all samples. A plot of $\mathrm{Sr}$ versus $\mathrm{Ca}$ (Fig. 4) shows that the PS series of samples fit a single mixing line within errors, except for Sample PS-2, which is $0.9 \%$ above the line; the other samples, which were subject to evaporation, lie well above the line. The concentrations in Samples PS-2, GO-2, IW 175, and IW 194 were normalized so that all samples fell on the mixing line defined by the other samples in the PS series, which were assumed to be unaffected by evapora- 


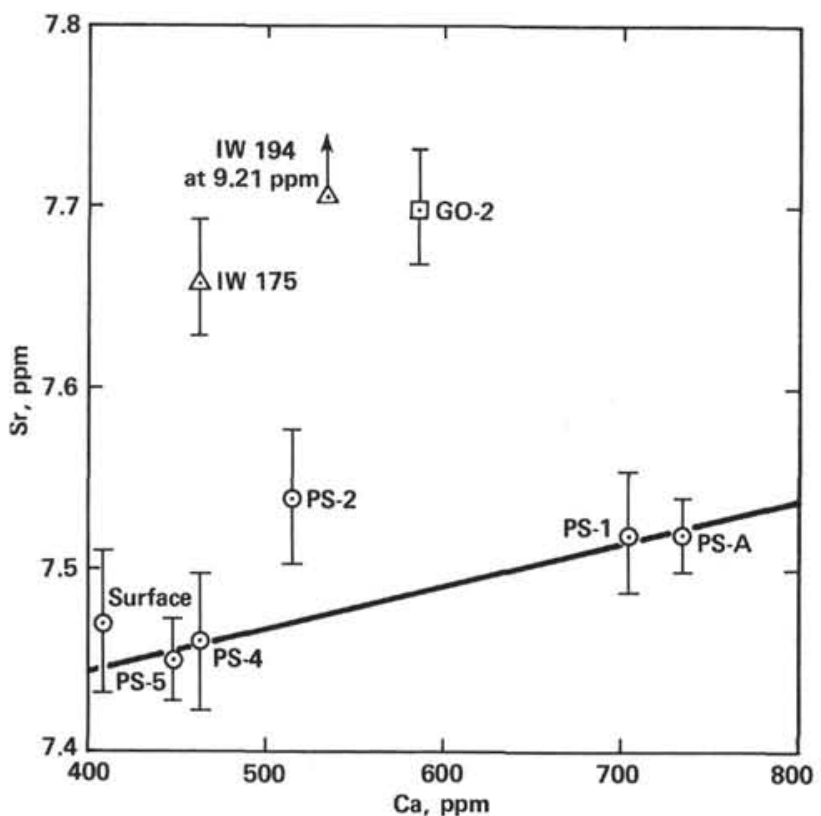

Figure 4. Sr versus $\mathrm{Ca}$ content of formation water mixtures. Four samples lie above a simple mixing curve due to evaporation effects during sample handling; otherwise, $\mathrm{Sr}$ concentrations are determined with a precision of $0.3 \%$ to $0.5 \%$.

tion. The atomic absorption data of Mottl, Anderson, et al. (this volume) confirmed the correctness of this procedure for Samples PS-2 and GO-2. The K contents of the samples normalized in this way are plotted against $\mathrm{Ca}$ in Figure 5; the data now fit a single mixing curve within error, except for the data for Samples GO-2 and IW 175 , which are slightly (1.6-1.8\%) above the line. A plot of ${ }^{87} \mathrm{Sr} /{ }^{86} \mathrm{Sr}$ versus $\mathrm{Sr}$ content (Fig. 6) also shows that this simple normalization procedure produces a fit of all samples to a single mixing line. Note also that the mixing lines in Figures 4 to 6 all pass through the surface seawater data, showing that the data are consistent with the expectation, based on the water sampling technique used, that the recovered samples are mixtures of the surface seawater used as drilling fluid and a basalt-reacted formation water.

\section{DISCUSSION}

If the $\mathrm{Ca}$ concentration in the presumed formation water end-member can be established, the mixing lines in Figures 1 and 4 to 6 can be used to deduce the values of $\mathrm{K}, \mathrm{Sr}$, and ${ }^{87} \mathrm{Sr} /{ }^{86} \mathrm{Sr}$ values for the formation water end-member. By using pore water data from the overlying sediments, Mottl et al. (this volume) derived a $\mathrm{Ca}$ content of $\sim 1340 \mathrm{ppm}$ for the end-member formation water. The resulting values of $\mathrm{K}, \mathrm{Sr}$, and ${ }^{87} \mathrm{Sr} /{ }^{86} \mathrm{Sr}$ for the formation water end-member are as given in Table 2 .

The formation waters collected at Hole 504B were at basement temperatures (as measured in situ) from $70^{\circ} \mathrm{C}$ (PS series samples, $201 \mathrm{~m}$ ) to $\sim 105^{\circ} \mathrm{C}$ (Sample IW 194, $440 \mathrm{~m}$ ). They thus represent interaction with the crust at temperatures intermediate between those normally observed at other sites in the upper 500 meters of crust $\left(15-80^{\circ} \mathrm{C}\right.$, from smectite oxygen thermometry, Staud-

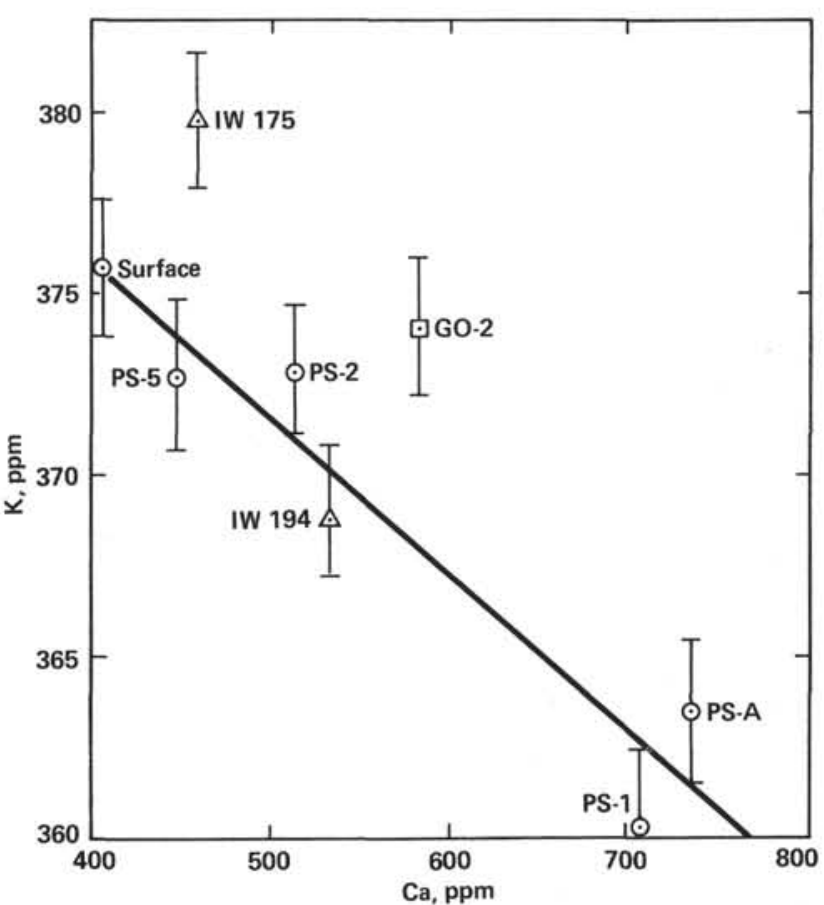

Figure 5. $\mathrm{K}$ versus $\mathrm{Ca}$ content of formation water mixtures. Analytical error in $\mathrm{K}$ is $\pm 0.5 \%$. The data for surface water, PS-2, GO-2, IW 175 , and IW 194 have been corrected down by $0.997 \%, 0.991 \%$, $0.972 \%, 0.974 \%$, and $0.801 \%$, respectively, to account for evaporation (as determined by forcing all data from Fig. 4 to fit a single mixing curve).

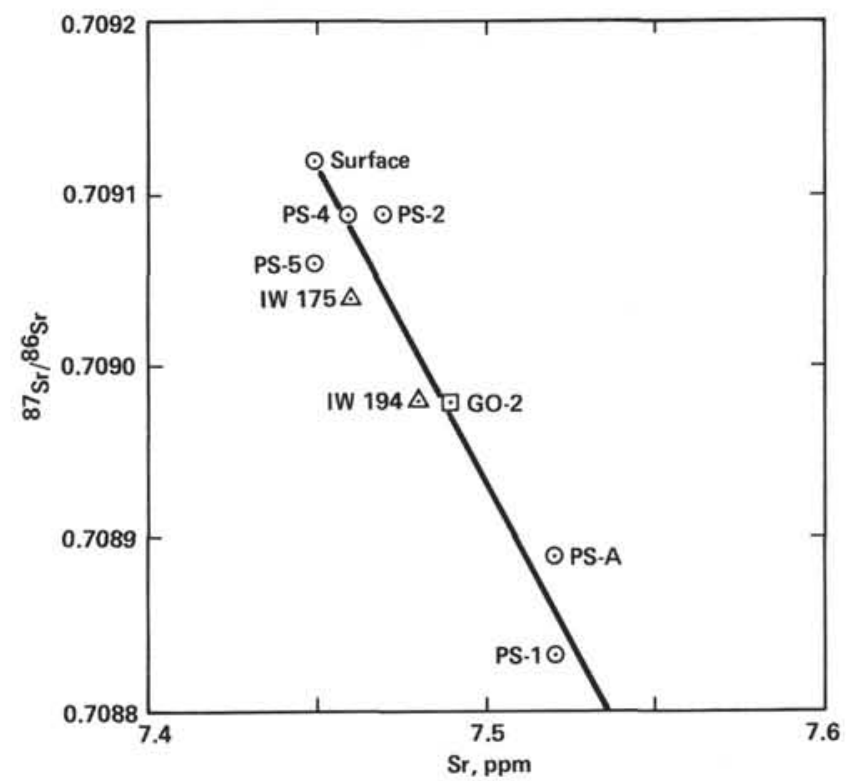

Figure $6 .{ }^{87} \mathrm{Sr} /{ }^{86} \mathrm{Sr}$ versus $\mathrm{Sr}$ content of formation water mixtures. $\mathrm{Sr}$ contents of some samples have been corrected for evaporation by the factors given in the Figure 5 legend. Analytical uncertainties (not shown) are $\pm 0.5 \%$ for $\mathrm{Sr}$ concentrations and from \pm 3 to \pm 8 $\times 10^{-5}$ for ${ }^{87} \mathrm{Sr} /{ }^{86} \mathrm{Sr}$ (Table 1). The data fit a single mixing line within these analytical uncertainties. Note that this mixing line is not completely independent, because the evaporation corrections were derived by forcing $\mathrm{Sr}$ in Figure 4 to fit a single line. 


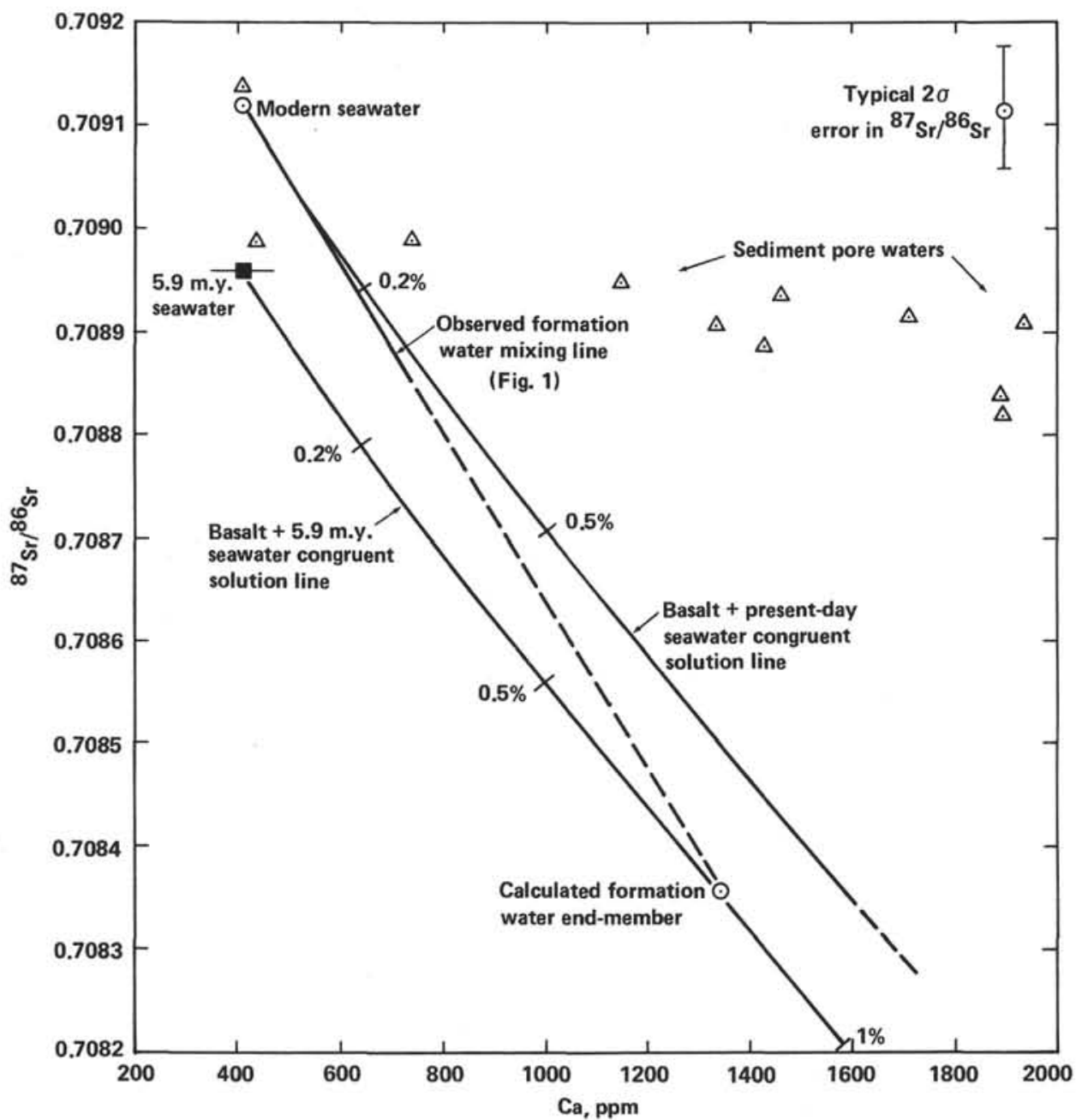

Figure $7 .{ }^{87} \mathrm{Sr} /{ }^{86} \mathrm{Sr}$ versus $\mathrm{Ca}$ mixing diagram. The observed formation water mixing line from Figure 1 is shown, with its extrapolation to the assumed fully reacted formation water end-member at $\mathrm{Ca} \approx 1340$ $\mathrm{ppm}$. Also shown are seawater/basalt congruent-solution or mixing lines, using either present-day or 5.9 m.y. old seawater as one end-member and basalt with ${ }^{87} \mathrm{Sr} / 86 \mathrm{Sr}=0.7027, \mathrm{Sr}=100 \mathrm{ppm}$, and $\mathrm{Ca}=12 \mathrm{wt} . \%$ as the other end-member. Tick marks are shown on this curve for $0.2 \%, 0.5 \%$, and $1 \%$ basalt by weight in the mixture. Also shown (open triangles) are data for ${ }^{87} \mathrm{Sr} /{ }^{86} \mathrm{Sr}$ and $\mathrm{Ca}$ in sediment pore waters from Holes 501 and 504.

The other components, such as $\mathrm{K}$ and $\mathrm{Sr}$, can be treated similarly. The $\mathrm{K}$ content is obviously incompatible with the simple congruent solution of basalt (see above), inasmuch as the $\mathrm{K}$ concentration of the formation water is lower than that of modern seawater. On a plot of ${ }^{87} \mathrm{Sr} /{ }^{86} \mathrm{Sr}$ versus $\mathrm{Sr}$ concentration (not shown), this simple mechanism also fails, inasmuch as the formation water plots far below a seawater/basalt mixing line. Furthermore, no reasonable choice of values for the seawater or the basalt end-member will accommodate the formation water data point. Thus, some combination of Processes 2 and 3 must have been involved in addition to or instead of the simple congruent solution. Isotopic exchange between basalt and seawater without accompanying $\mathrm{Sr}$ elemental exchange (Process 2 ) would lower the $\mathrm{Sr}$ isotope ratio without affecting the $\mathrm{Sr}$ concentration and produce a formation water value that lies below a simple mixing curve on a plot of ${ }^{87} \mathrm{Sr} /{ }^{86} \mathrm{Sr}$ ver- sus $\mathrm{Sr}$. The removal of $\mathrm{Sr}$ from solution by the deposition of Sr-containing alteration minerals (Process 3) would have the same result. The latter process would not necessarily show up in a plot of ${ }^{87} \mathrm{Sr} /{ }^{86} \mathrm{Sr}$ versus $\mathrm{Ca}$ (Fig. 7) if the Sr were being removed in smectites, which typically have $\mathrm{Sr} / \mathrm{Ca}$ ratios much higher than basalt.

One final insight may be derived from Figure 7, which also includes $\mathrm{Sr}$ isotope data for the pore waters from sediments from Holes 501 and 504. The trends of the $\mathrm{Sr}$ isotope ratio with respect to $\mathrm{Ca}$ are completely different for the pore waters and the formation waters. Although the ${ }^{87} \mathrm{Sr} /{ }^{86} \mathrm{Sr}$ ratio for the low-Ca pore waters is consistent with derivation from 5.9 m.y. old seawater, the $\mathrm{Sr}$ isotope ratio decreases measurably more slowly than the 5.9 m.y. old seawater with increasing Ca content. This implies the existence of a minor basaltic component in the sediment pore waters, a component derived either from reaction with volcanogenic detritus 
within the sediments themselves or from a slight admixture of basalt-containing formation water from the basement beneath the sediments.

In either event, the disparity between the trends in the pore water and the formation water (Fig. 7) may warrant the reconsideration of the estimated $\mathrm{Ca}$ content of the formation water end-member (Table 2), which was derived by analogy with the $\mathrm{Ca}$ content of the pore water from the sediment closest to the basement surface. This pore water cannot be an unreacted sample of formation water, at least with respect to ${ }^{87} \mathrm{Sr} /{ }^{86} \mathrm{Sr}$ and $\mathrm{Sr}$ content. It is possible that significant $\mathrm{Sr}$ isotope equilibration took place between the sediment pore waters and the carbonate of the sediment during diagenesis. If so, the difference between pore water $\mathrm{Sr}$ and formation water ${ }^{87} \mathrm{Sr} /{ }^{86} \mathrm{Sr}$ is consistent with the determination of the formation water $\mathrm{Ca}$ content by analogy with the pore water $\mathrm{Ca}$ contents.

\section{ACKNOWLEDGMENTS}

We thank M. Bender for the two Leg 70 formation waters and for helpful discussions. This work was supported by NSF Grant OCE-7909457 (to S. R. H.) and NSF Grant OCE-8019056 (to M. J. M.). We are grateful for the analytical help of M. Roden, the electronic wizardry of $\mathrm{K}$. Burrhus, the graphic support of D. Hall, the word processing skills of T. Miele and D. Berry, and the critical reviews by S. Richardson and G. Thompson. H. Staudigel and S. Richardson were inspiring companions in contiguous and associated crimes.

\section{REFERENCES}

Albarede, F., Vitrac-Michard, A., Minster, J. F., and Michard, G., 1980. Strontium isotopic composition in hydrothermal systems. Eos, 61:994-995.

Aldrich, L. T., Doak, J. B., and Davis, G. L., 1953. The use of ion exchange columns in mineral analysis for age determination. Amer. J. Sci., 251:377-387.

Anderson, R. N., Langseth, M. G., and Sclater, J. G., 1977. The mechanisms of heat transfer through the floor of the Indian Ocean. J. Geophys. Res., 82:3391-3409.

Andrews, A. J., 1977. Low temperature fluid alteration of oceanic layer 2 basalts, DSDP Leg 37. Can. J. Earth Sci., 14:911-926.

Bernat, M., Church, T., and Allegre, C. J., 1972. Barium and strontium concentrations in Pacific and Mediterranean sea water profiles by direct isotope dilution mass spectrometry. Earth Planet. Sci. Lett., 16:75-80.

Böhlke, J. K., Honnorez, J., and Honnorez-Guerstein, B.-M., 1980. Alteration of basalts from Site 396B, DSDP: Petrographic and mineralogic studies. Contrib. Mineral. Petrol., 73:341-364.

Edmond, J. M., 1981. The chemistry of ridge crest hydrothermal activity. In Presnall, D. C., Hales, A. L., and Frey (Convenors), The Generation of Oceanic Lithosphere. Chapman Conference Progr. (Am. Geophys. Union). (Abstract)
Edmond, J. M., Measures, C., McDuff, R. E., Chan, L. H., Collier, R., Grant, B., Gordon, L. I., and Corliss, J. B., 1979. Ridge crest hydrothermal activity and the balances of the major and minor elements in the ocean: the Galapagos data. Earth Planet. Sci. Lett., 46:1-18.

Edmond, J. M., Measures, C., Mangum, B., Grant, B., Sclater, F. R., Collier, R., Hudson, A., Gordon, L. I., and Corliss, J. B., 1979. On the formation of metal-rich deposits at ridge crests. Earth Planet. Sci. Lett., 46:19-30.

Elder, J. W., 1965. Physical processes in geothermal areas. In Lee, W. H. K. (Ed.), Terrestrial Heat Flow: Washington (Am. Geophys. Union), pp. 211-239.

Hart, S. R., and Brooks, C., 1977. The geochemistry and evolution of early Precambrian mantle. Contrib. Mineral. Petrol., 61:109-128.

Hart, S. R., and Staudigel, H., 1978. Oceanic crust: age of hydrothermal alteration. Geophys. Res. Lett., 5:1009-1012.

Hildreth, R. A., and Henderson, W. T., 1971. Comparison of $\mathrm{Sr}^{87}$ / $\mathrm{Sr}^{86}$ for seawater strontium and the Eimer and $\mathrm{Amend} \mathrm{SrCO}_{3}$. Geochim. Cosmochim. Acta, 35:235-238.

Holland, H. D., 1978. The Chemistry of the Atmosphere and Oceans: New York (Wiley-Interscience), p. 192.

Honnorez, J., Böhkle, J. K., and Honnorez-Guerstein, B. M., 1979. Petrographical and geochemical study of the low temperature submarine alteration of basalt from Hole 396B, Leg 46. In Dmitriev, L., Heirtzler, J., et al., Init. Repts. DSDP, 46: Washington (U.S. Govt. Printing Office), 299-318.

Humphris, S. E., and Thompson, G., 1978a. Hydrothermal alteration of oceanic basalts by seawater. Geochim. Cosmochim. Acta, 42: $107-125$.

, 1978b. Trace element mobility during hydrothermal alteration of oceanic basalts. Geochim. Cosmochim. Acta, 42:127-136.

Mevel, C., 1980. Mineralogy and chemistry of secondary phases in low temperature altered basalts from Deep Sea Drilling Project Legs 51, 52, and 53. In Donnelly, T., Francheteau, J., Bryan, W., Robinson, P., Flower, M., Salisbury, M., et al., Init. Repts. $D S D P, 51,52,53$, Pt. 2: Washington (U.S. Govt. Printing Office) 1299-1317.

Papanastassiou, D. A., and Wasserburg, G. J., 1978. Strontium isotopic anomalies in the Allende meteorite. Geophys. Res. Lett., 5: 595-598.

Pritchard, R. G., 1980. Alteration of basalts from Deep Sea Drilling Project Legs 51, 52, and 53, Holes 417A and 418A. In Donnelly, T., Francheteau, J., Bryan, W., Robinson, P., Flower, M., Salisbury, M., et al., Init. Repts. DSDP, 51, 52, 53, Pt. 2: Washington (U.S. Govt. Printing Office), 1185-1199.

Richardson, S. H., Hart, S. R., and Staudigel, H., 1980. Vein mineral ages of old oceanic crust. J. Geophys. Res., 85:7195-7200.

Robinson, P. T., Flower, M. F. J., Schminke, H.-U., and Ohnmacht, W., 1977. Low temperature alteration of oceanic basalts, DSDP Leg 37. In Aumento, F., Melson, W. G., et al., Init. Repts. DSDP, 37: Washington (U.S. Govt. Printing Office), 775-793.

Staudigel, H., Hart, S. R., and Richardson, S. H., 1981. Alteration of the oceanic crust: processes and timing. Earth Planet. Sci. Lett., 52:311-327.

Staudigel, H., Muehlenbachs, K., Richardson, S. H., and Hart, S. R., 1981. Agents of low temperature ocean crust alteration. Contrib. Mineral. Petrol., 77:150-157.

Wolery, T. J., and Sleep, N.H., 1976. Hydrothermal circulation and geochemical flux at mid-ocean ridges. J. Geol., 84:249-276. 